\title{
LOGIT MODELS FOR EARLY WARNING OF DISTRESSED CAPITAL PROJECTS
}

\author{
Hong Long Chen \\ Department of Business and Management, National University of Tainan, \\ No. 33, Sec. 2, Shu-Lin St., Tainan 700, Taiwan \\ E-mail: along314@mail.nutn.edu.tw \\ Received 11 October 2011; accepted 09 July 2012
}

\begin{abstract}
The focus of this study is to demonstrate how probabilistic models may be employed to provide early warnings for distressed capital projects. While identifying the key determinants of project performance is important, few studies test discriminatory power of variables for predicting distressed capital projects. Thus, this longitudinal study of 121 capital projects identifies key variables in the initiation and planning phases of projects that differentiate between healthy and distressed projects at completion. Subsequent univariate logistic analysis shows that the Quality variable provides the highest univariate classification accuracy. Hierarchical logistic-regression analysis reveals high classification accuracy and relatively small differences in overall classification rates. Out-of-sample forecasting validation demonstrates that the optimal model provides a reasonably good overall classification rate of $85.37 \%$. Ultimately, our findings suggest that it is feasible to discriminate simultaneously between healthy and distressed projects prior to the project execution phase in the capital facility delivery process, providing an early warning of projects in distress.
\end{abstract}

Keywords: capital projects, distressed projects, early warning signs, performance assessment, logit analysis, longitudinal study.

Reference to this paper should be made as follows: Chen, H. L. 2013. Logit models for early warning of distressed capital projects, Journal of Business Economics and Management 14(Supplement 1): S145-S167.

JEL Classification: L74, M11, N65.

\section{Introduction}

A central tenet of the study of project management is to identify the critical determinants of project performance. Of course, extensive research in the project management field examines and identifies a wide variety of measures that describe project performance and the inputs that affect the performance. Some studies emphasize the importance of the execution phase on project performance and identify the critical factors associated with the execution phase (e.g., Chen et al. 2010; Hoegl, Parboteeah 2007; Keller 1986, 1992, 1994; Tabassi, Bakar 2009). Others suggest examining and identifying the critical factors of project performance on the basis of the overall project life cycle (e.g., El- 
Sayegh 2008; Ibbs et al. 2001; Ling et al. 2009; Oke, Idiagbon-Oke 2010; Scott-Young, Samson 2008; Zou et al. 2007).

However, despite the panoply of studies into which factors affect project performance (e.g., Chen et al. 2010; El-Sayegh 2008; Oke, Idiagbon-Oke 2010; Schieg 2007; ScottYoung, Samson 2008), few longitudinally test discriminatory power of variables in the early stage of the project delivery process for differentiating between healthy and distressed capital projects at completion. The capital projects industry includes both the delivery and the maintenance of facilities such as commercial and institutional, industrial, and residential buildings. Our focus is on the delivery process of capital projects, e.g., from the initiating to closing phases of projects. Thus, there appears to be a lack of studies that provide early warning models for predicting distressed capital projects. The study of early warning models is important because it enables management to intervene early into the affairs of problem projects so that corrective actions can be taken before it is too late.

The first objective of this study, therefore, is to conduct a longitudinal experiment that examines discriminatory power of variables associated with the project-initiation and planning phases on capital project outcomes - those variables not in the project execution phase or the overall project life cycle, but rather, specifically in the project-initiation and planning phases. One of the obvious benefits of such an experiment design is that it warns managers of distressed projects before the execution phase in the capital project delivery process. The second objective is to assess, through multivariate logit modelbuilding and validation, how well the variables detect healthy and distressed capital projects.

The rest of the paper is organized as follows. "Research Background" reviews related studies, "Hypotheses" delineates the test hypotheses, "Research Methods" presents the research methodology and describes the sample collection, and "Results" depicts the statistical tests, model-building, and validation. "Discussion" discusses the implications of the research results. "Conclusion" presents the research summary and conclusions.

\section{Research Background}

A central tenet of the study of project performance is that identifying specific impacts on project performance will guide project managers to engineer critical issues scientifically during project execution. Not surprisingly, researchers and professional associations (e.g., Anand et al. 2010; Brown et al. 1990; Cao, Hoffman 2011; El-Mashaleh et al. 2010; Ghosh, Skibniewski 2010; Hoang, Rothaermel 2005; Hsu et al. 2011; Keller 1986; Ling et al. 2009; Project Management Institute 2008; Qureshi et al. 2009; Zeng et al. 2009) conduct extensive studies to examine and identify these key determinants of project performance.

For example, Keller (1986) examines 32 project groups in a large R\&D organization using a longitudinal design based on hierarchical regression analysis and concludes that group cohesiveness, physical distance, job satisfaction, and innovative orientation are factors in project performance. Brown et al. (1990) assess 14 project teams that 
worked on the same complex, computer-simulated project using ANOVA and regression analysis; they conclude that group harmony significantly influences the performance of a project.

Additionally, Keller (1992) evaluates 66 project groups in three industrial R\&D organizations using a longitudinal experiment based on factor analysis and regression analysis. He concludes that transformational leadership, which is the sum of charismatic leadership and intellectual stimulation, significantly affects the performance of projects. Using the data from 98 project groups in four industrial R\&D organizations, Keller (1994) further tests the hypothesis that a fit between the task technology's characteristics and information-process needs predicts project performance. Concurrent and one-year-later management ratings of project quality, based on absolute-difference scores as a measure of fit, support the hypothesis.

Subsequent work by Hoegl and Gemuenden (2001) and Hoegl et al. (2003) uses regression analysis to examine the effects of teamwork quality on project performance. Based on data from 145 projects in four software development organizations, they conclude that teamwork quality is associated with the performance of projects posing high task innovativeness. Further, Hoang and Rothaermel (2005) use binary logistic analysis to examine the success of 158 joint R\&D projects in 43 pharmaceutical firms; they claim that the general alliance experience of biotechnology partners, but not of pharmaceutical firms, positively affects joint project outcomes.

Song et al. (2007) conclude that initial planning conditions and the effectiveness of front-end planning management affect how well R\&D plans and the later R\&D process perform based on two R\&D projects. Similarly, Schwab and Anne (2008) examine 239 U.S. movie projects from 1931 to 1940 and determine, using regression analysis, that project performance depends on the perceived relevance of prior performance and on organizational control over project participants.

Using data from 56 capital projects in 15 process-industry companies, Scott-Young and Samson (2008) examine the impact of organizational context, team design, team leadership, and team process factors on project performance using factor analysis and regression analysis. Their test results show that these factors are significant determinants of project outcomes. More recently, Hoang and Rothaermel (2010) examine 412 R\&D projects in 43 pharmaceutical companies from 1980 to 2000 and conclude, using a competing risk event history model, that alliance exploitation experience positively affects R\&D project performance. They also show that when firms combine internal exploitation experience with external exploration experience, the negative effects on R\&D project performance occur and are more significant.

Recently, Anand et al. (2010) analyze 98 projects in five companies using hierarchical regression. They show that the inclusion of softer, people-oriented practices for capturing tacit knowledge explains a significant amount of variance in project outcomes. Shepherd et al. (2011) use hierarchical regression analysis to examine the effects of negative emotions and affective commitment resulted from project failure on subsequent project performance. Based on data from 257 research scientists about project teams in 
12 different research institutes in Germany, they conclude that emotions as outcomes may influence emotions as inputs for subsequent projects; that is, the negative emotions of project failure create an affective commitment to the organization.

More recently, Calamel et al. (2012) examine two collaborative R\&D projects in a large global innovation cluster in France using a longitudinal design based on in-depth case research. They conclude that team collaboration, a product of social construction fostered by managerial support, is important factor in project performance.

Although many studies use a wide variety of measures to describe project performance and the input characteristics that affect the performance (e.g., Anand et al. 2010; Dumont et al. 1997; Hoegl et al. 2003; Ibbs et al. 2001; Oke, Idiagbon-Oke 2010; Song et al. 2007; Sperpell 1999), most studies emphasize the project-execution phase (e.g., Chen et al. 2010; Hoegl, Parboteeah 2007; Keller 1986, 1992, 1994; Tabassi, Bakar 2009) or the overall project life cycle (e.g., El-Sayegh 2008; Ibbs et al. 2001; Oke, Idiagbon-Oke 2010; Scott-Young, Samson 2008; Zou et al. 2007).

Further, most studies identify the critical determinants of project performance using contemporaneous data (e.g., Chen et al. 2010; El-Sayegh 2008; Ibbs et al. 2001; Ling et al. 2009; Oke, Idiagbon-Oke 2010; Scott-Young, Samson 2008; Shepherd et al. 2011). Limited studies examine the potential predictors of project performance using longitudinal data.

In particular, although few published studies examine the potential predictors of project performance using longitudinal data, these studies (e.g., Calamel et al. 2012; Keller $1986,1992,1994)$ emphasize the project-execution phase and mainly focus on new product development (NPD) and research and development (R\&D) - despite the fact that capital projects contribute significant growth to the economy (Chen 2010; Mallick, Mahalik, 2010). As a result, there appears to be a lack of research that longitudinally examines what variables possess a potential discriminatory power to differentiate between healthy and distressed projects prior to the project execution phase in the capital facility delivery process.

\section{Hypotheses}

The preceding section critiques existing studies of project performance. Now the question is: What variables in the project-initiation and planning phases can discriminate between healthy and distressed capital projects at completion?

To answer this question, test hypotheses have to be developed. From an extensive review of the interdisciplinary literature along with consultation with several experienced researchers and practitioners and in an effort to generate a more parsimonious measurement, we choose widely accepted variables that are used to measure the performance of the overall project life cycle for hypothesis tests. These performance variables include Scope, Quality, Team, Communication, Risk, Change, and Innovation.

Scope. Defining a project's scope is a process by which the project is outlined and prepared for execution (Dumont et al. 1997). Whilst a project scope is a detailed for- 
mulation of a continuous strategy to be used throughout a project to achieve the project objectives, defining the scope is one of the principal tasks in the project-initiation and planning phases. A poorly defined project scope can experience considerable changes, resulting in cost overruns, delays in the project schedule, rework, disrupted project rhythm, and lower productivity (Dumont et al. 1997). Not surprisingly, several studies (e.g., Görög 2011; Kwak, Ibbs 2002; Ling et al. 2009; Roman 1964) report that scope management is one of the leading influences on project performance for all project types. Therefore, we form the first hypothesis:

H1: The Scope variable in the project-initiation and planning phases can discriminate between healthy and distressed capital projects at completion.

Quality. High-quality projects create end products that fully meet customer needs, reduce rework of nonconforming tasks, keep customers informed of the progress, and change to meet emerging customer requirements (Tukel, Rom 2001). Thus, whilst quality management starts at the project's initiation, effective quality management ensures the project to meet its requirements in the project delivery process. Naturally, effective quality management has become one of the most frequently studied project performance factors (e.g., Al-Tmeemy et al. 2012; Ling et al. 2009; Sperpell 1999). Thus, this study proposes that levels of quality performance in the project-initiation and planning phases will be associated with project outcomes at completion. We form the second hypothesis:

H2: The Quality variable in the project-initiation and planning phases can discriminate between healthy and distressed capital projects at completion.

Team. Studies have long recognized team quality as a key factor in overall project performance (e.g., Bendoly, Swink 2007; Brown et al. 1990; Keller 1986; Raiden et al. 2004; Scott-Young, Samson 2008). Despite the general management literature's increasing interest in team quality, project teams are still under-researched in project management (e.g., Anand et al. 2010; Chen et al. 2010; Hsu et al. 2011; Ling et al. 2009; Scott-Young, Samson 2008; Tabassi, Bakar 2009; Thamhain 2009). One recent finding, for example, is that team leadership has significant impact on both the project team and its broader organizational environment, ultimately affecting project performance (Thamhain 2009); another is that the ability to apply and share team knowledge effectively explains a significant amount of variance in project performance (Hsu et al. 2011). Thus, we propose the third hypothesis:

H3: The Team variable in the project-initiation and planning phases can discriminate between healthy and distressed capital projects at completion.

Communication. A project involving a number of specialists performing related activities aimed at achieving a predetermined goal requires communication among those specialists (Blankevoort 1984). For over 20 years, research has found that communication quality influences project performance (Clark, Fujimoto 1991; Leonard-Barton, 1995). The reason is clear: communication supports knowledge sharing and hence the performance of projects (Adenfelt 2010; Badir et al. 2012; Ochieng, Price 2010). Thus, we propose that levels of communication performance in the project-initiation and planning phases will be associated with project outcomes at completion. 
H4: The Communication variable in the project-initiation and planning phases can discriminate between healthy and distressed capital projects at completion.

Risk. Risk is the potential for complications and problems with respect the achievement of a project goal (Cohen, Palmer 2004). Though a recent study of the relationship between risk management and project success did not yield conclusive results (De Bakker et al. 2010; Schieg 2006), a general consensus is that effective risk management positively affects the success rate of any project or process in various industries (e.g., Raz et al. 2002; Cook 2005; Holzmann, Spiegler 2011; Das, Teng 1999). In particular, the Project Management Institute (PMI) and the Association of Project Management (APM) include risk management as one of the key disciplines of project management. Thus, we propose the fifth hypothesis:

H5: The Risk variable in the project-initiation and planning phases can discriminate between healthy and distressed capital projects at completion.

Change. Change is an unplanned disturbance that typically interferes with the intended progression of project work (Love et al. 2002). Changes during a project's development may have significant and often unpredictable effects on the project's organization and management (Ibbs et al. 2001; Lehmann 2010; Luu et al. 2008). Many time delays, cost overruns, and quality defects can be attributed to changes at various stages of a project (Sun, Meng 2009). Not surprisingly, a project teams' ability to manage change determines project performance to a large extent (Hwang, Low 2012). Hence, we predict that managing change well in the project-initiation and planning phases is associated with superior project outcomes at completion.

H6: The Change variable in the project-initiation and planning phases can discriminate between healthy and distressed capital projects at completion.

Innovation. Innovation often manifests itself in either a new product, service, process, or method (Brady, Söderlund 2008). The relationship between innovation and project management has drawn much research in recent years. Several studies find that better innovation management increases the chances of project success (Chapman, Hyland 2004; Dulaimi et al. 2005; Kratzer et al. 2006; Oke, Idiagbon-Oke 2010). For example, Beaume et al. (2009) conclude a significant interplay between project performance and innovation management based on the comparison analysis of five case studies in the automotive industry. Biedenbach and Müller (2012) show that innovative capability affects innovation output positively, which in return has an impact on short- and longterm project performance, based on data from 18 interviews and 80 surveys with R\&D project managers and officers in the pharmaceutical-biotechnology industry. Thus, we propose that levels of innovation performance in the project-initiation and planning phases will be associated with project outcomes at completion.

H7: The Innovation variable in the project-initiation and planning phases can discriminate between healthy and distressed capital projects at completion. 


\section{Research methods}

\subsection{Participants and procedures}

Of the 500 members of Taiwan's Chinese National Association of General Contractors (CNAGC) that we randomly selected and invited to participate in this research, 121 companies participated - a $24.2 \%$ response rate (CNAGC has over 1,000 members). Each of the 121 companies in the sample had assigned a project manager who had just completed the initiation and planning of a capital project scheduled to finish within the next two years. The 121 capital projects fall into three categories: buildings (69 projects composed of 21 commercial buildings, 39 residential buildings, and nine public buildings), transportation facilities (22 projects composed of 15 roadway construction and seven bridge construction), and industrial facilities (30 projects composed of 21 industrial buildings and nine utility systems). Project managers average between one and 26 years of experience; 30 participants had fewer than five years of experience; 51 had between five and 10 years; 33 had between 10 and 20 years; and seven participants had over 20 years of experience. Table 1 provides the sample characteristics.

Surveys collected the data. Prior to the data collection, several experienced researchers and a panel of experts from CNAGC critiqued the questionnaire for structure, readability, clarity, and completeness. These researchers and experts also appraised the extent to which the indicators sufficiently addressed the subject area (Dillman 1978). Based on the feedback from these researchers and experts, the survey instrument was then modified to strengthen its validity.

The final version of the survey questionnaire comprises two sections. The first section, composed of open-ended questions, gathers detailed background information, such as annual revenue, project types, project cost including contract price, budget, contract price for project change, and actual cost, and the project schedule including the contract schedule, scheduled time, contract schedule for project change, and actual schedule.

The second section gathers data for the project variables and is measured by scales based on a synthesis of literature from the project management, group effectiveness, organizational theory, and innovation management fields. Section two consists of multiple-choice questions in which respondents indicate on a 10-point scale the extent to which certain project variables likely affected the project outcomes. Because of space limitations, complete survey questionnaires are not presented here but are available from the authors on request.

Data collection occurred in two stages. In the first stage, participants respond immediately after the end of a project's initiation and planning stages to the portion of the questionnaire that excludes questions regarding project actual cost, project actual schedule, contract price and schedule for project change, and actual cost and schedule for project change. In the second stage, participants respond right after the close of the capital project to the questions excluded in stage one. 
Table 1. Sample characteristics

\begin{tabular}{|c|c|}
\hline Variables & Value \\
\hline \multicolumn{2}{|l|}{ Responses } \\
\hline Organizations invited to participate in the research & 500 \\
\hline Organizations participating & 121 \\
\hline Participation rate $(\%)$ & 24.2 \\
\hline \multicolumn{2}{|l|}{ Annual net revenue of organizations (in US\$ millions) } \\
\hline Less than 5 & 24 \\
\hline $5-15$ & 30 \\
\hline $15-25$ & 37 \\
\hline Over 25 & 30 \\
\hline \multicolumn{2}{|l|}{ Types of capital projects } \\
\hline Buildings & 69 \\
\hline Commercial buildings & 21 \\
\hline Residential buildings & 39 \\
\hline Public buildings & 9 \\
\hline Transportation facilities & 22 \\
\hline Roadways & 15 \\
\hline Bridges & 7 \\
\hline Industrial facilities & 30 \\
\hline Buildings & 21 \\
\hline Utility systems & 9 \\
\hline \multicolumn{2}{|l|}{ Years of experience as a project manager } \\
\hline Fewer than 5 & 30 \\
\hline $5-10$ & 51 \\
\hline $10-20$ & 33 \\
\hline Over 20 & 7 \\
\hline \multicolumn{2}{|l|}{ Project contract price (in US\$ millions) } \\
\hline Less than 1 & 33 \\
\hline $1-10$ & 57 \\
\hline $10-20$ & 15 \\
\hline Over 20 & 16 \\
\hline
\end{tabular}

\subsection{Measures and analysis}

Cost, time, and performance are the typical measures of project outcomes (Kloppenborg, Opfer 2002). In other words, a project is often considered healthy (or successful) if it finishes within its budget estimate, finishes within its scheduled time frame, and performs as designed (Scott-Young, Samson 2008). Whilst the research literature in project management engages in a fruitful debate over the nature of project success (Dvir et al. 1998), project outcome criteria have become multifaceted.

Thus, this study chooses project time, cost, and profitability as the criteria for capital project outcomes. The rationales are straightforward: delays in completion time may turn a promising investment opportunity into an expensive failure (Scott-Young, Sam- 
son 2008), cost overrun directly encroaches on profit (Teerajetgul et al. 2009), and project profitability ensures business growth and development (Chen 2011).

In addition, the cost, time, and profitability metrics are objective in nature, allowing a direct comparison of projects with different types, scopes, and sizes across different industries, especially when the metrics are binary measures (Scott-Young, Samson 2008). Consequently, our dependent variable, Project Outcome, is binary, with 1 indicating that a capital project finishes within budget and scheduled time frame and makes a profit; otherwise, it is 0 .

Measures of project performance variables, including Scope, Quality, Team, Communication, Risk, Change, and Innovation, are based on a detailed examination of literature in project management, group effectiveness, organization theory, and innovation management; consultation with several experienced researchers; and consultation with a panel of experts from CNAGC. The work identifies these measures that are similar to the project performance measures most project contracting organizations use internally for assessing the performance of the overall project life cycle. If not otherwise indicated, all measures use a scale in which 1 is "strongly disagree" and 10 is "strongly agree". High scores suggest good performance; low scores indicate poor performance.

Scope $(\alpha=.97)$ is measured according to a four-item scale based on Dumont et al. (1997), Görög (2011), Ling et al. (2009), Kwak and Ibbs (2002), and Roman (1964). The four items are "Quality of contract documents including project definitions, legal terms, specifications, design instructions, and implementation processes is good", "Project owner defines project scope well", "Project owner has verified extent of project scope well", and "Work breakdown structure (WBS) of the project is well defined and manageable".

Quality $(\alpha=.96)$ is measured according to a four-item scale based on Ling et al. (2009), Roman (1964), and Sperpell (1999). The four items include "Quality-management plan clearly describes how quality assurance (QA) will be performed", "Every quality metric clearly describes what something is and how to measure it", "Quality checklist verifies that a set of required steps is complete", and "Quality baseline is established and well defined".

Team $(\alpha=.98)$ is measured according to a 12-item scale based on Anand et al. (2010), Bendoly and Swink (2007), Brown et al. (1990), Chen et al. (2010), Chen and Lee (2007), Hoegl and Parboteeah (2007), Hoegl et al. (2003), Hsu et al. (2011), Keller (1986), Ling et al. (2009), Raiden et al. (2004), Scott-Young and Samson (2008), Song et al. (2007), Tabassi and Bakar (2009), and Thamhain (2009). Items are "Top management support for the project team is high", "Each team member's project role, responsibilities, and rights are clearly defined", "Enthusiasm about project success is high", "Group participation in decision-making is high", "Interpersonal relationships among team members is good", "Project teams' job skills and expertise are good". , "Degree of cohesiveness of the project team is high", "Degree of motivation of the project team is high", "Degree of cooperation of the project team is high", "Quality of group decisions of the project is high", "Degree of team-building is high", and "Degree of conflict resolution and problem solving of the project team is high." 
Communication $(\alpha=.97)$ is measured according to a six-item scale based on Barclay and Osei-Bryson (2010), Bendoly and Swink (2007), Chen et al. (2010), Emhjellen (1997), Huesemann (2006), Ling et al. (2009), and Oke and Idiagbon-Oke (2010). The six items are "The project team identifies all the key stakeholders of the project", "The project team meets the information needs of the stakeholders", "The project team meets the communications needs of the stakeholders", "Technology use in information sharing is high", "Communication with the customer is effective", and "Communication within project team members is effective".

Risk $(\alpha=.94)$ is measured according to a four-item scale based on El-Sayegh (2008) and Zou et al. (2007). The four items include "Project team handles customer design changes well", "Project team handles lack of defined scope of work well", "Project team handles lack of or departure of qualified staff well", and "Project team handles delays in resolving contractual issues well".

Change $(\alpha=.97)$ is measured according to a three-item scale based on Ibbs et al. (2001), Lehmann (2010), and Luu et al. (2008). The three items are "The project team continually improves from lessons learned", "The project team brings the appropriate parties into the discussion for the requested change", and "The project team negotiates changes and communicates them to all affected parties".

Innovation $(\alpha=.97)$ is measured according to a 10-item scale based on Ciptono (2006), Dulaimi et al. (2005), Kazanjian et al. (2000), Keller (1994), Kratzer et al. (2006), Miron-Spektor et al. (2007), Song et al. (2007), and Tranfield et al. (2003). Items are "Management support for innovation is high", "Project team applies latest technology to the project", "Project team devotes much time and resources toward generating innovative ideas", "Team members have diverse skills", "Cognitive conflict among project team members is high", "The project manager adopts a bottom-up problem-solving style that incorporates all team members", "There are widespread communications within/ across the project", "Extent of elaborating information processing and coordination mechanisms within/across the project is high", "Roles of team members are determined through interaction among project members of different functions", and "The delegation of autonomy and decision authority to the project manager is high".

Confirmatory factor analyses reveal that all the factor loadings of the measurement items of Scope, Quality, Team, Communication, Risk, Change, and Innovation are significant $(p<0.05)$ and all are 0.79 or greater, which all exceed the threshold value of 0.5 (Hair et al., 1998). We therefore include all in the project performance measurement model. The resulting measurement model provides a fair fit to the data, with $\chi^{2}=1501$, $d f=860$, RMSEA $=0.08$, and CFI $=0.87$.

The methodology to analyze the potential predictors of project outcomes is threefold. First, to verify the hypotheses, this study uses the Kolmogorov-Smirnov test to verify normality, followed by T-tests and Mann-Whitney tests, respectively, when the data is normally and abnormally distributed. Subsequent to the equality of mean tests, this study uses univariate logistic-regression analysis to evaluate the variables' predictive ability. Second, based on the significant predictors determined in step one, this study 
conducts a hierarchical logistic-regression analysis using a maximum Nagelkerke Rsquared improvement procedure to develop optimal project-outcome prediction models. Third, this study evaluates the out-of-sample forecasting accuracy of the prediction models using Type I errors (i.e., a healthy project misclassified as a distressed project), Type II errors (i.e., a distressed project misclassified as a healthy project), and overall correct classification rates.

We split the sample into two subsamples: the estimation data and the out-of-sample forecast data. The estimation data, composed of 80 projects randomly selected from 121 capital projects, are used for the hypothesis tests and model-building. We use the out-of-sample forecast data - the remaining 41 projects - to study the models' predictive ability.

\section{Results}

\subsection{Results of hypothesis tests}

Table 2 lists the descriptive statistics and results of Kolmogorov-Smirnov tests, T-tests, and Mann-Whitney tests for the hypothesis. The use of Mann-Whitney tests for Quality and Change variables is justified by the fact that the data are not normally distributed based on the result of Kolmogorov-Smirnov tests, where the data are judged abnormally distributed when the probability value is smaller than the threshold value of 0.05 .

Table 2. Descriptive statistics, Kolmogorov-Smirnov tests, T-tests and Mann-Whitney tests for the hypotheses

\begin{tabular}{|c|c|c|c|c|c|c|c|c|c|}
\hline \multirow{2}{*}{$\frac{\frac{0}{\pi}}{\frac{\pi}{3}}$} & \multirow[b]{2}{*}{$\sum_{\Sigma}^{\varpi \Xi}$} & \multirow{2}{*}{$\stackrel{\Xi}{\Xi}$} & \multirow{2}{*}{ 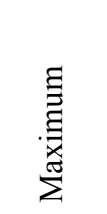 } & \multicolumn{2}{|c|}{$\begin{array}{l}\text { Kolmogorov- } \\
\text { Smirnov } \\
\text { Test } \mathrm{N}=80^{\mathrm{a}}\end{array}$} & \multicolumn{2}{|c|}{$\begin{array}{c}\text { T-Test } \\
\mathrm{N}=80\end{array}$} & \multicolumn{2}{|c|}{$\begin{array}{c}\text { Mann-Whitney } \\
\text { Test } \\
N=80\end{array}$} \\
\hline & & & & Statistic & $\begin{array}{l}\text { Prob- } \\
\text { ability }\end{array}$ & Statistic & $\begin{array}{l}\text { Prob- } \\
\text { ability }\end{array}$ & Statistic & $\begin{array}{l}\text { Prob- } \\
\text { ability }\end{array}$ \\
\hline Scope & 7.166 & 3.000 & 10.000 & 0.081 & 0.200 & 6.496 & $<0.001$ & - & - \\
\hline Quality & 7.188 & 4.000 & 10.000 & 0.162 & 0.000 & - & - & 332.00 & $<0.001$ \\
\hline Team & 7.420 & 4.000 & 10.000 & 0.084 & 0.200 & 6.793 & $<0.001$ & - & - \\
\hline $\begin{array}{l}\text { Communi- } \\
\text { cation }\end{array}$ & 6.959 & 4.000 & 10.000 & 0.094 & 0.078 & 5.403 & $<0.001$ & - & - \\
\hline Risk & 6.763 & 3.000 & 10.000 & 0.084 & 0.200 & 5.984 & $<0.001$ & - & - \\
\hline Change & 6.959 & 3.670 & 10.000 & 0.101 & 0.043 & - & - & 392.00 & $<0.001$ \\
\hline Innovation & 6.724 & 4.000 & 9.800 & 0.099 & 0.053 & 4.612 & $<0.001$ & - & - \\
\hline
\end{tabular}

Notes: Project is healthy $(=1), 1$ when profitability $=1$, cost $=1$, and time $=1$ exist; otherwise, it is distressed $(=0)$.

${ }^{a} 52$ projects are healthy, and 28 projects are distressed. Performance ratings of scope, quality, team, communication, risk, change, and innovation were collected right after the end of the initiation and planning phases of a capital project; the contract price and schedule for project change, project actual cost, and project actual schedule were gathered right after the close of the project. 
Profitability $=$ Revised profit performance $=($ revised contract price - actual cost $) /$ actual cost, where the revised contract price includes the cost of scope changes. When larger than 0 , it is coded as 1 ; otherwise, it is 0 .

Cost $=$ Revised cost performance $=$ revised estimated cost/actual cost, where the revised estimated cost includes the estimated cost of scope changes. When smaller than 1 , it is coded as 0 ; otherwise, it is 1 .

Time $=$ Revised time performance $=$ revised estimated duration/actual duration, where the revised estimated duration includes the estimated duration of scope changes. When smaller than 1 , it is coded as 0 ; otherwise, it is 1 .

As the table shows, a significant difference exists in the mean values of distressed and nondistressed projects from Scope, Quality, Team, Communication, Risk, Change, and Innovation in the project-initiation and planning phases. Significance of difference in means exists when the probability of the Mann-Whitney test and T-test is smaller than 0.05 .

All the hypotheses are therefore accepted, suggesting that the Scope, Quality, Team, Communication, Risk, Change, and Innovation variables in the project-initiation and planning phases possess a potential discriminatory power for differentiating between distressed and nondistressed projects at completion.

This study further performs a series of univariate logistic-regression analyses to evaluate how well these variables differentiate between healthy and distressed projects, as shown in Table 3. The univariate logistic-regression coefficients of Scope, Quality, Team, Communication, Risk, Change, and Innovation are 1.27, 1.38, 0.88, 0.93, 1.21, 0.68, and 0.89 with $p$-values of $<0.01$, respectively. The results confirm that Scope, Quality, Team, Communication, Risk, Change, and Innovation are significant univariate predictors of project outcomes and demonstrate very high classification ability, ranging from $73.75 \%$ to $82.50 \%$ with Nagelkerke R-squared values from 0.21 to 0.50 ; Quality provides the highest univariate classification accuracy.

Table 3. Univariate logistic analysis results

\begin{tabular}{lcccc}
\hline \multicolumn{1}{c}{ Variable } & $\mathrm{B}^{\mathrm{a}}$ & $\operatorname{Exp}(\mathrm{B})$ & Nagelkerke R-squared & Overall Correct (\%) \\
\hline Scope & $1.27^{* *}$ & 3.57 & 0.49 & 77.50 \\
\hline Quality & $1.38^{* *}$ & 3.96 & 0.50 & 82.50 \\
\hline Team & $0.88^{* *}$ & 2.42 & 0.29 & 75.00 \\
\hline Communication & $0.93^{* *}$ & 2.52 & 0.21 & 73.75 \\
\hline Risk & $1.21^{* *}$ & 3.36 & 0.44 & 78.75 \\
\hline Change & $0.68^{* *}$ & 1.98 & 0.36 & 75.00 \\
\hline Innovation & $0.89^{* *}$ & 2.43 & 0.28 & 75.00 \\
\hline
\end{tabular}

Notes: ${ }^{\text {aCCefficient; }}{ }^{*} P<0.05$ and ${ }^{* *} P<0.01$. 


\subsection{Model-building}

The hypothesis tests suggest that Scope, Quality, Team, Communication, Risk, Change, and Innovation in the initiation and planning phases are significant predictors of project outcomes. Based on the findings, this study further examines whether logit models developed from these predictors differentiate between healthy and distressed projects, making it possible to identify distressed projects early in the process, and thus providing an early warning of distressed projects. This study, therefore, conducts a series of hierarchical logistic-regression analyses using a maximum Nagelkerke R-squared improvement procedure to develop optimal project-outcome prediction models from the estimation data of the 80 projects.

Table 4 reports the model-building results. As the table shows, the optimal projectoutcome forecasting model at step 1 (Model 1) is the one with the Quality variable, where $50 \%$ of the variation in the estimation data is explained; the corresponding Type I error, Type II error, and overall correct classification rates are $32.14 \%, 9.62 \%$, and $82.50 \%$. At step 2, the optimal project-outcome forecasting model (Model 2), composed of the Quality and Scope variables, explains 53\% of the variation in the performance data, which is $3 \%$ more than that of Model 1 . The Type I error, Type II error, and overall correct classification rates are $32.14 \%, 13.46 \%$, and $80.00 \%$, respectively.

The optimal models at steps 3, 4, 5, and 6 (Models 3, 4, 5, and 6) are composed of Quality, Scope, and Team; Quality, Scope, Team, and Change; Quality, Scope, Team, Change, and Communication; and Quality, Scope, Team, Change, Communication, and Innovation, respectively. These models explain 57\%, 58\%, 58\%, and 59\% of the variation in the estimation data, respectively. The respective Type I error, Type II error, and overall correct classification rates of Models 3, 4, 5, and 6 are 25.00, 7.69, and 86.25; 25.00, 9.62, and 85.00; 25.00, 9.62, and 85.00; and 21.43, 7.69, and 87.50. Because the Nagelkerke R-square values do not improve after Model 6, Model 7 is not presented in the table. Consequently, Model 6 is the optimal project-outcome forecasting model.

Whilst the correlation matrix reveals that many of the independent variables are more strongly correlated with one another than with the dependent variable Project Outcome, detecting multicollinearity that may impair the model's estimated parameters by inflating their variances is important. Table 5 thus reports the multicollinearity diagnostics of Model 6, where the column labeled Condition Number (indicating the square root of the ratio of the largest to smallest eigenvalue) indicates the degree of near-linear dependencies. Eigenvalues have condition numbers larger than 30, and variables with variation proportions greater than 0.5 for each of these eigenvalues are involved in the near-linear dependency (Belsley et al. 1980). As the table shows, although the condition numbers of eigenvalues 4,5 , and 6 are larger than 30, only the Team variable of the fourth Eigenvalue has a 0.53 variation proportion. This indicates that Team is the only variable correlated with the fourth Eigenvalue. Consequently, multicollinearity does not exist in the model. 


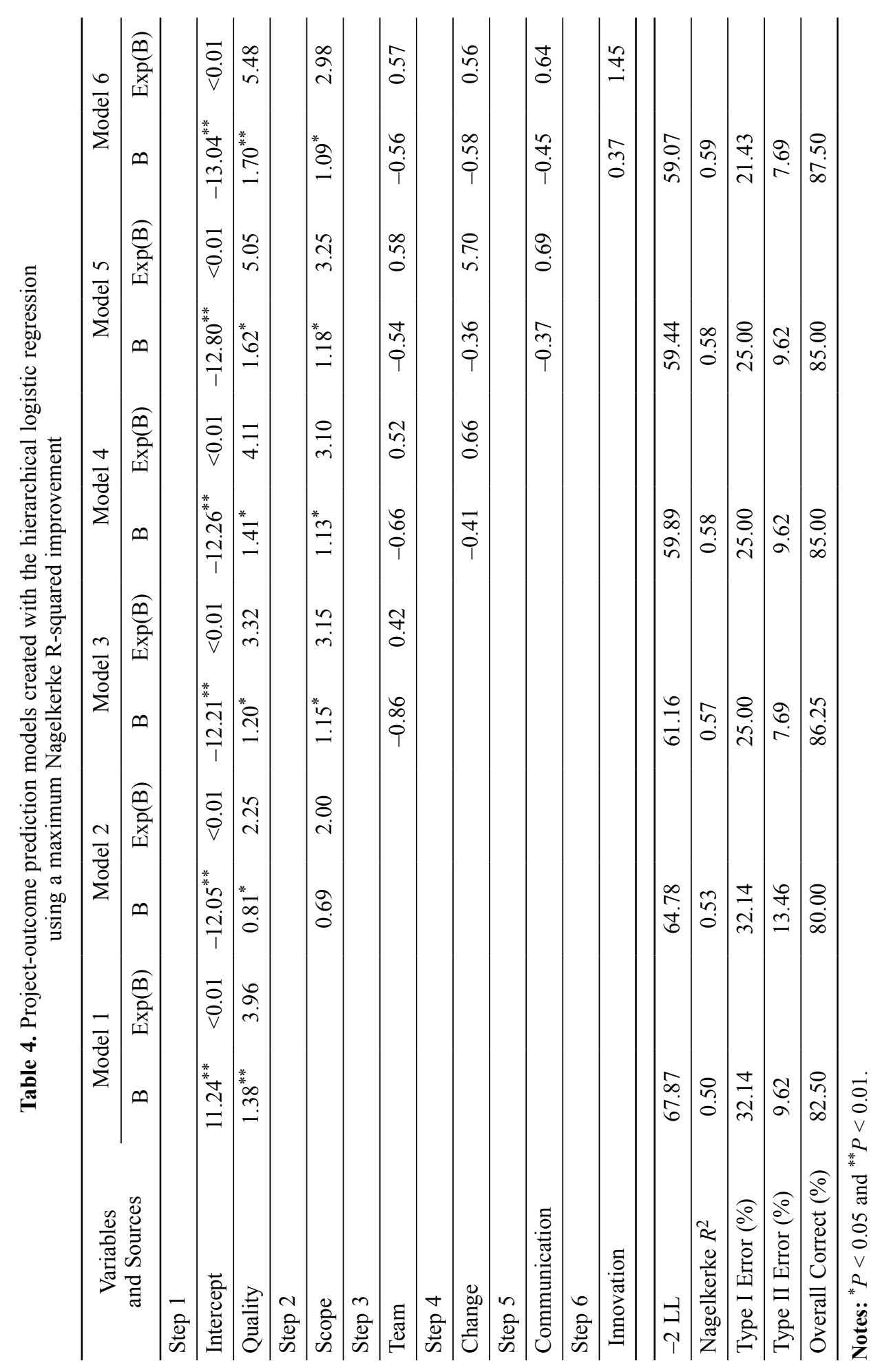


Table 5. Multicollinearity diagnostics of project-outcome prediction model (Model 6)

\begin{tabular}{|c|c|c|c|c|c|c|c|c|}
\hline \multirow{2}{*}{$\begin{array}{l}\text { Principal } \\
\text { Component }\end{array}$} & \multirow[b]{2}{*}{ Eigenvalue } & \multirow{2}{*}{$\begin{array}{l}\text { Condition } \\
\text { Number }\end{array}$} & \multicolumn{6}{|c|}{ Proportion of Variation } \\
\hline & & & Scope & Team & Quality & Change & $\begin{array}{l}\text { Commu- } \\
\text { nication }\end{array}$ & Innovation \\
\hline 1 & 6.94 & 1.00 & $<0.01$ & $<0.01$ & $<0.01$ & $<0.01$ & $<0.01$ & $<0.01$ \\
\hline 2 & 0.03 & 15.49 & 0.02 & $<0.01$ & $<0.01$ & $<0.01$ & 0.02 & $<0.01$ \\
\hline 3 & 0.01 & 22.25 & 0.23 & $<0.01$ & 0.02 & 0.20 & $<0.01$ & 0.07 \\
\hline 4 & 0.01 & 31.31 & 0.38 & 0.53 & $<0.01$ & 0.06 & 0.10 & 0.02 \\
\hline 5 & 0.01 & 31.93 & 0.20 & 0.25 & 0.24 & 0.02 & 0.16 & 0.08 \\
\hline 6 & 0.00 & 40.18 & $<0.01$ & 0.21 & 0.14 & 0.32 & 0.40 & 0.33 \\
\hline
\end{tabular}

\subsection{Evaluation of forecast accuracy}

Type I error, Type II error, and overall correct classification rates evaluate out-of-sample forecasting accuracy using data from 41 of the 121 capital projects. Table 6 reports the out-of-sample forecasts from the project-outcome prediction model (Model 6).

Table 6. Out-of-sample forecasts by project-outcome prediction model (Model 6a)

\begin{tabular}{|c|c|c|c|c|c|c|c|c|c|}
\hline \multirow{2}{*}{$\begin{array}{l}\text { Project } \\
\text { Number }\end{array}$} & \multicolumn{6}{|c|}{ Predictor } & \multirow[b]{2}{*}{$P(Y)^{\mathrm{b}}$} & \multirow{2}{*}{$\hat{P}(Y)^{\mathrm{c}}$} & \multirow{2}{*}{$\begin{array}{l}\text { Prediction } \\
\text { Error }^{\mathrm{d}}\end{array}$} \\
\hline & Scope & Team & Quality & Change & $\begin{array}{l}\text { Commu- } \\
\text { nication }\end{array}$ & Innovation & & & \\
\hline 81 & 6.75 & 6.25 & 9.42 & 7.33 & 9.00 & 7.80 & 1 & 0.78 & \\
\hline 82 & 6.50 & 6.50 & 6.67 & 6.50 & 7.33 & 6.90 & 0 & 0.06 & \\
\hline 83 & 9.50 & 8.50 & 8.42 & 8.17 & 8.33 & 8.50 & 1 & 0.83 & \\
\hline 84 & 8.00 & 9.00 & 9.42 & 8.83 & 8.33 & 7.60 & 1 & 0.67 & \\
\hline 85 & 8.00 & 9.00 & 9.25 & 8.33 & 8.33 & 7.90 & 1 & 0.68 & \\
\hline 86 & 9.00 & 8.00 & 8.67 & 8.00 & 8.00 & 8.00 & 1 & 0.86 & \\
\hline 87 & 7.00 & 7.00 & 8.00 & 7.17 & 7.67 & 6.50 & 0 & 0.28 & \\
\hline 88 & 6.75 & 7.00 & 7.50 & 6.67 & 6.33 & 5.80 & 0 & 0.21 & \\
\hline 89 & 7.25 & 7.25 & 8.50 & 7.83 & 7.00 & 7.50 & 0 & 0.62 & II \\
\hline 90 & 7.50 & 8.00 & 8.58 & 8.50 & 9.00 & 9.00 & 0 & 0.40 & \\
\hline 91 & 7.50 & 7.00 & 7.83 & 8.00 & 8.00 & 8.00 & 1 & 0.33 & I \\
\hline 92 & 6.25 & 5.25 & 6.92 & 6.00 & 5.00 & 4.40 & 1 & 0.21 & I \\
\hline 93 & 8.75 & 9.00 & 9.33 & 9.00 & 10.00 & 9.10 & 1 & 0.71 & \\
\hline 94 & 6.00 & 7.00 & 6.83 & 6.50 & 0.00 & 2.10 & 0 & 0.28 & \\
\hline 95 & 8.75 & 8.00 & 8.00 & 8.00 & 8.00 & 7.00 & 1 & 0.51 & \\
\hline 96 & 4.75 & 4.75 & 5.33 & 4.33 & 5.33 & 5.10 & 0 & 0.01 & \\
\hline 97 & 2.50 & 2.00 & 3.25 & 2.50 & 3.33 & 3.50 & 0 & 0.00 & \\
\hline 98 & 6.75 & 6.50 & 7.83 & 6.50 & 7.67 & 7.80 & 0 & 0.39 & \\
\hline 99 & 5.50 & 5.25 & 6.33 & 6.83 & 6.67 & 5.50 & 0 & 0.02 & \\
\hline
\end{tabular}


End of Table 6

\begin{tabular}{|c|c|c|c|c|c|c|c|c|c|}
\hline \multirow{2}{*}{$\begin{array}{l}\text { Project } \\
\text { Number }\end{array}$} & \multicolumn{6}{|c|}{ Predictor } & \multirow[b]{2}{*}{$P(Y)^{\mathrm{b}}$} & \multirow{2}{*}{$\hat{P}(Y)^{\mathrm{c}}$} & \multirow{2}{*}{$\begin{array}{l}\text { Prediction } \\
\text { Error }^{\mathrm{d}}\end{array}$} \\
\hline & Scope & Team & Quality & Change & $\begin{array}{l}\text { Commu- } \\
\text { nication }\end{array}$ & Innovation & & & \\
\hline 100 & 5.25 & 5.00 & 6.33 & 4.83 & 6.33 & 5.60 & 0 & 0.04 & \\
\hline 101 & 6.50 & 6.50 & 6.83 & 7.00 & 7.00 & 7.00 & 1 & 0.07 & I \\
\hline 102 & 4.75 & 4.25 & 5.08 & 4.50 & 4.00 & 3.40 & 0 & 0.01 & \\
\hline 103 & 6.75 & 7.00 & 7.33 & 7.00 & 8.00 & 7.10 & 0 & 0.10 & \\
\hline 104 & 5.25 & 6.00 & 5.83 & 5.50 & 0.00 & 1.80 & 0 & 0.07 & \\
\hline 105 & 6.00 & 6.00 & 5.92 & 5.83 & 6.00 & 5.00 & 0 & 0.02 & \\
\hline 106 & 4.25 & 4.25 & 4.75 & 4.00 & 4.67 & 4.60 & 0 & 0.00 & \\
\hline 107 & 2.00 & 2.00 & 2.83 & 2.00 & 2.33 & 2.70 & 0 & 0.00 & \\
\hline 108 & 5.75 & 5.50 & 6.83 & 5.50 & 6.67 & 6.80 & 0 & 0.12 & \\
\hline 109 & 4.50 & 4.25 & 5.33 & 5.83 & 5.67 & 4.50 & 0 & 0.00 & \\
\hline 110 & 4.75 & 4.50 & 5.50 & 4.50 & 5.33 & 5.00 & 0 & 0.01 & \\
\hline 111 & 8.50 & 9.00 & 9.83 & 10.00 & 10.00 & 9.80 & 1 & 0.78 & \\
\hline 112 & 7.50 & 5.75 & 7.83 & 6.50 & 4.33 & 4.50 & 1 & 0.82 & \\
\hline 113 & 8.75 & 10.0 & 9.17 & 9.00 & 9.33 & 9.60 & 1 & 0.65 & \\
\hline 114 & 7.50 & 6.00 & 8.33 & 8.00 & 5.00 & 6.00 & 1 & 0.85 & \\
\hline 115 & 9.50 & 8.00 & 8.08 & 8.17 & 8.00 & 7.00 & 1 & 0.71 & \\
\hline 116 & 5.25 & 5.25 & 5.92 & 4.67 & 6.00 & 5.70 & 0 & 0.03 & \\
\hline 117 & 2.50 & 2.00 & 3.25 & 2.50 & 3.33 & 3.50 & 0 & 0.00 & \\
\hline 118 & 7.75 & 7.50 & 8.83 & 7.50 & 8.67 & 8.80 & 0 & 0.76 & II \\
\hline 119 & 7.50 & 7.25 & 8.00 & 8.33 & 8.67 & 7.50 & 1 & 0.22 & $\mathrm{I}$ \\
\hline 120 & 5.25 & 5.00 & 6.33 & 4.83 & 6.33 & 5.60 & 0 & 0.04 & \\
\hline 121 & 7.50 & 7.00 & 8.67 & 6.67 & 8.33 & 8.10 & 1 & 0.76 & \\
\hline
\end{tabular}

Notes: ${ }^{a}$ Model $6=-13.04+1.09$ Scope -0.56 Team +1.70 Quality -0.58 Change -0.450 .64 Communication +0.37 Innovation, where Nagelkerke $R^{2}=0.59$.

${ }^{\mathrm{b}} P(Y)=1$ when a healthy project exists; otherwise, $P(Y)=0$.

${ }^{c} \hat{P}(Y)$ is the predicted likelihood of a healthy project by Model 6 . The cutoff point is 0.5 (i.e., when it is smaller than 0.5 , it is distressed; otherwise, healthy).

${ }^{d}$ I is Type I error, II is Type II error. The average Type I and II errors of out-of-sample forecasts are $23.53 \%(4 / 17)$ and $8.33 \%(2 / 24)$, respectively; the overall correct rate is $85.37 \%(6 / 41)$.

As seen in the table, the respective average Type I error, Type II error, and correct classifications of the out-of-sample forecast data in Model 6 are 23.53\%, 8.33\%, and $85.37 \%$, respectively; those for the estimation data in Model 6 (see Table 4) are $21.43 \%$, $7.69 \%$, and $87.5 \%$, respectively. The relatively smaller differences in the average Type I error, Type II error, and correct rates for the estimation data and the out-of-sample forecast data in Model 6 indicates that the project-outcome prediction model based on Scope, Team, Quality, Change, Communication, and Innovation is viable and practical. 


\section{Discussions}

The results of this study support the hypotheses that Scope, Quality, Team, Communication, Risk, Change, and Innovation in the initiation and planning phases of capital projects possess a potential discriminatory power for differentiating between distressed and nondistressed projects at completion. The findings also indicate that when these variables perform well in the initiation and planning phases of a project, the project is more likely to meet its budget, schedule, and profitability goals. Specifically, our findings reported here suggest that project managers should encourage the development of effective scope management, effective teamwork, risk management, effective communication, innovation, effective quality management, and ability to handle change during a project's initiation and planning phases.

Subsequent univariate logistic analysis results further support the hypotheses that Scope, Quality, Team, Communication, Risk, Change, and Innovation in the initiation and planning phases of capital projects are significant predictors of project outcomes assessed on the triple measure set of cost, time, and profitability. The results also show that Quality provides the highest univariate classification accuracy; the rest of the variables follow closely, indicating a class of stable predictors. Hierarchical logistic-regression analysis using a maximum Nagelkerke R-squared improvement procedure reveals a high classification accuracy for Models 1 to 6 (see Table 4) that ranges from $80.00 \%$ to $87.50 \%$ with relatively small difference in the overall classification rates, ranging from $1.25 \%$ to $7.50 \%$. The out-of-sample forecasting validation shows that the optimal prediction model (Model 6), composed of Scope, Quality, Team, Communication, Change, and Innovation, provides a reasonably good overall classification rate of $85.37 \%$.

In sum, the findings demonstrate that these variables possess a strong, stable, discriminatory performance for differentiating between healthy and distressed projects. The findings suggest that it is feasible to discriminate simultaneously between healthy and distressed projects prior to the project execution phase in the capital facility delivery process, providing an early warning of projects in distress. It is also significant that these variables hold up as a predictor across different types of capital projects.

\section{Conclusions}

Although scope, quality, team, communication, risk, change, and innovation are key determinants of project performance, few studies assess how these variables in the projectinitiation and planning phases affect project outcomes. This study therefore investigates the relationship between these variables and project outcomes. The longitudinal data in this study suggest that the variables have a strong, stable, discriminatory power to predict distressed projects. A multivariate logit prediction model on the longitudinal data demonstrates that a combination of Scope, Quality, Team, Communication, Change, and Innovation provides the highest overall classification accuracy for estimation and holdout samples ( $87.50 \%$ and $85.37 \%$, respectively).

Our findings regarding the importance of Scope, Quality, Team, Communication, Change, and Innovation are consistent with prior studies based on the project-execu- 
tion phase (e.g., Chen et al. 2010; Hoegl, Parboteeah 2007; Keller 1986, 1992, 1994; Tabassi, Bakar 2009; Wang et al. 2005) and the overall project life cycle (e.g., Duffy, Thomas 1989; El-Sayegh 2008; Ibbs et al. 2001; Ling et al. 2009; Oke, Idiagbon-Oke 2010; Scott-Young, Samson 2008; Zou et al. 2007). The present research extends the state of knowledge concerning the predictive power of these variables during the successive phases before capital projects become distressed, as well as the relationship between the project-initiation and planning phases and the predictability of distressed capital projects.

As an extension of this research in this paper, a study of the interactions among time, cost and profitability along with the impacts of Scope, Quality, Team, Communication, Risk, Change, and Innovation variables would be beneficial because it gives management additional information about not only tradeoffs among time, cost, and profitability, but the critical determinants of each time, cost and profitability in the project-initiation and planning phases.

Another extension of the research to a broader evaluation of these variables that includes NPD and R\&D projects will provide management a comprehensive picture of how the predictive power of these variables varies under different types of projects. In another extension of the research to a study of the relationships between improved performance of scope, quality, team, communication, risk, change, and innovation and the likelihood of distress on projects throughout the project-delivery process, it would be beneficial in decision-making, management, and project control.

\section{Acknowledgment}

We would like to thank the Taiwan National Science Council for financially supporting this research.

\section{References}

Adenfelt, M. 2010. Exploring the performance of transnational projects: shared knowledge, coordination and communication, International Journal of Project Management 28(6): 529-538. http://dx.doi.org/10.1016/j.ijproman.2009.10.004

Al-Tmeemy, S. M.; Abdul- Rahman, H.; Harun, Z. 2012. Contractors' perception of the use of costs of quality system in Malaysian building construction projects, International Journal of Project Management 30(7): 827-838. http://dx.doi.org/10.1016/j.ijproman.2011.12.001

Anand, G.; Ward, P. T.; Tatikonda, M. V. 2010. Role of explicit and tacit knowledge in Six Sigma projects: an empirical examination of differential project success, Journal of Operations Management 28(4): 303-315. http://dx.doi.org/10.1016/j.jom.2009.10.003

Badir, Y. F.; Büchel, B; Tucci, C. L. 2012. A conceptual framework of the impact of NPD project team and leader empowerment on communication and performance: an alliance case context, International Journal of Project Management 30(8): 914-926.

Barclay, C.; Osei-Bryson, K. M. 2010. Project performance development framework: an approach for developing performance criteria \& measures for information systems (IS) projects, International Journal of Production Economics 124(1): 272-292.

http://dx.doi.org/10.1016/j.ijpe.2009.11.025 
Beaume, R.; Maniak, R.; Midler, C. 2009. Crossing innovation and product projects management: a comparative analysis in the automotive industry, International Journal of Project Management 27(2): 166-174. http://dx.doi.org/10.1016/j.ijproman.2008.09.004

Belsley, D. A.; Kuh, E.; Welsch, R. E. 1980. Regression Diagnostics. New York: John Wiley \& Son. http://dx.doi.org/10.1002/0471725153

Bendoly, E.; Swink, M. 2007. Moderating effects of information access on project management behavior, performance and perceptions, Journal of Operations Management 25(3): 604-622. http://dx.doi.org/10.1016/j.jom.2006.02.009

Biedenbach, T; Müller, R. 2012. Absorptive, innovative and adaptive capabilities and their impact on project and project portfolio performance, International Journal of Project Management 30(5): 621-635. http://dx.doi.org/10.1016/j.ijproman.2012.01.016

Blankevoort, P. J. 1984. Effects of communication and organization, International Journal of Project Management 2(3): 138-147. http://dx.doi.org/10.1016/0263-7863(84)90013-9

Brady, T.; Söderlund, J. 2008. Projects in innovation, innovation in projects selected papers from the IRNOP VIII conference, International Journal of Project Management 26(5): 465-468. http://dx.doi.org/10.1016/j.ijproman.2008.06.007

Brown, K. A.; Klastorin, T. D.; Valluzzi, J. 1990. Project performance and the liability of group harmony, IEEE Transactions on Engineering Management 37(2): 117-125.

http://dx.doi.org/10.1109/17.53714

Calamel, L.; Defélixa, C.; Picqd, T.; Retour, D. 2012. Inter-organisational projects in French innovation clusters: the construction of collaboration, International Journal of Project Management 30(1): 48-59.

Cao, Q.; Hoffman, J. J. 2011. A case study approach for developing a project performance evaluation system, International Journal of Project Management 29(2): 155-164.

http://dx.doi.org/10.1016/j.ijproman.2010.02.010

Chapman, R.; Hyland, P. 2004. Complexity and learning behaviors in product innovation, Technovation 24(7): 553-561. http://dx.doi.org/10.1016/S0166-4972(02)00121-9

Chen, H. L. 2010. Using financial and macroeconomic indicators to forecast sales of large development and construction corporations, Journal of Real Estate Finance and Economics 40(3): 310-331. http://dx.doi.org/10.1007/s11146-008-9158-7

Chen, H. L. 2011. An empirical examination of project contractors' supply-chain cash flow performance and owners' payment patterns, International Journal of Project Management 29(5): 604-614. http://dx.doi.org/10.1016/j.ijproman.2010.04.001

Chen, S. H.; Lee, H. T. 2007. Performance evaluation model for project managers using managerial practices, International Journal of Project Management 25(6): 543-551.

http://dx.doi.org/10.1016/j.ijproman.2007.03.004

Chen, W. T.; Chang, P. Y.; Huang, Y. H. 2010. Assessing the overall performance of value engineering workshops for construction projects, International Journal of Project Management 28(5): 514-527. http://dx.doi.org/10.1016/j.ijproman.2009.08.005

Ciptono, W. S. 2006. A sequential model of innovation strategy - company non-financial performance links, Gadjah Mada International Journal of Business 8(2): 137-178.

Clark, K. B.; Fujimoto, T. 1991. Product development performance: strategy, organization and management in the world auto industry. Boston, MA: Harvard Business School Press.

Cohen, M. W.; Palmer, G. R. 2004. Project risk identification and management, AACE International Transactions IN11-IN15.

Cook, P. 2005. Formalized risk management: vital tool for project- and business-success, Cost Engineering 47(8): 12-13. 
Das, T. K.; Teng, B. S. 1999. Managing risks in strategic alliances, The Academy of Management Executive 13(4): 50-62.

De Bakker, K.; Boonstra, A.; Wortmann, H. 2010. Does risk management contribute to IT project success? A meta-analysis of empirical evidence, International Journal of Project Management 28(5): 493-503. http://dx.doi.org/10.1016/j.ijproman.2009.07.002

Dillman, D. A. 1978. Mail and telephone surveys: the total design method. New York: Wiley.

Duffy, P. J.; Thomas, R. D. 1989. Project performance auditing, International Journal of Project Management 7(2): 101-104. http://dx.doi.org/10.1016/0263-7863(89)90022-7

Dulaimi, M. F.; Nepal, M. P.; Park, M. 2005. A hierarchical structural model of assessing innovation and project performance, Construction Management and Economics 23(6): 565-577. http://dx.doi.org/10.1080/01446190500126684

Dumont, P.; Gibson, E.; Fish, J. 1997. Scope management using project definition rating index, Journal of Management in Engineering 13(5): 54-60.

http://dx.doi.org/10.1061/(ASCE)0742-597X(1997)13:5(54)

Dvir, D.; Lipovetsky, S.; Shenhar, A.; Tishler, A. 1998. In search of project classification: a nonuniversal approach to project success factors, Research Policy 27(9): 915-935.

http://dx.doi.org/10.1016/S0048-7333(98)00085-7

El-Mashaleh, M. S.; Rababeh, S. M.; Hyari, K. H. 2010. Utilizing data envelopment analysis to benchmark safety performance of construction contractors, International Journal of Project Management 28(1): 61-67. http://dx.doi.org/10.1016/j.ijproman.2009.04.002

El-Sayegh, S. M. 2008. Risk assessment and allocation in the UAE construction industry, International Journal of Project Management 26(4): 431-438.

http://dx.doi.org/10.1016/j.ijproman.2007.07.004

Emhjellen, K. 1997. Adapting benchmarking to project management: an analysis of project management processes, metrics, and benchmarking process models. Doctoral thesis, Norwegian University of Science and Technology, Norway.

Ghosh, S.; Skibniewski, M. J. 2010. Enterprise resource planning systems implementation as a complex project: a conceptual framework, Journal of Business Economics and Management 11(4): 533-549. http://dx.doi.org/10.3846/jbem.2010.26

Görög, M. 2011. Translating single project management knowledge to project programs, Project Management Journal 42(2): 17-31.

Hair, J. F.; Anderson, R. E.; Tatham, R. L.; Black, W. C. 1998. Multivariate data analysis. Upper Saddle River, NJ: Prentice-Hall International Inc.

Hoang, H.; Rothaermel, F. T. 2005. The effect of general and partner-specific alliance experience on joint R\&D project performance, Academy of Management Journal 48(2): 332-345.

http://dx.doi.org/10.5465/AMJ.2005.16928417

Hoang, H.; Rothaermel, F. T. 2010. Leveraging internal and external experience: exploration, exploitation, and R\&D project performance, Strategic Management Journal 31(7): 734-758.

Hoegl, M.; Gemuenden, H. G. 2001. Teamwork quality and the success of innovative projects: a theoretical concept and empirical evidence, Organization Science 12(4): 435-449.

http://dx.doi.org/10.1287/orsc.12.4.435.10635

Hoegl, M.; Parboteeah, K. P. 2007. Creativity in innovative projects: how teamwork matters, Journal of Engineering and Technology Management 24(1-2): 148-166.

http://dx.doi.org/10.1016/j.jengtecman.2007.01.008

Hoegl, M.; Parboteeah, K. P.; Gemuenden, H. G. 2003. When teamwork really matters: task innovativeness as a moderator of the teamwork-performance relationship in software development projects, Journal of Engineering and Technology Management 20(4): 281-302.

http://dx.doi.org/10.1016/j.jengtecman.2003.08.001 
Holzmann, V.; Spiegler, I. 2011. Developing risk breakdown structure for information technology organizations, International Journal of Project Management 29(5): 537-547.

http://dx.doi.org/10.1016/j.ijproman.2010.05.002

Hsu, J. S. C.; Chang, J. Y. T.; Klein, G.; Jiang, J. J. 2011. Exploring the impact of team mental models on information utilization and project performance in system development, International Journal of Project Management 29(1): 1-12. http://dx.doi.org/10.1016/j.ijproman.2009.12.001

Huesemann, S. 2006. Information sharing across multiple humanitarian organizations - a webbased information exchange platform for project reporting, Information Technology and Management 7(4): 277-291. http://dx.doi.org/10.1007/s10799-006-0277-7

Hwang, B. G.; Low, L. K. 2012. Construction project change management in Singapore: status, importance and impact, International Journal of Project Management 30(7): 817-826.

http://dx.doi.org/10.1016/j.ijproman.2011.11.001

Ibbs, C. W.; Wong, C. K.; Kwak, Y. H. 2001. Project change management system, Journal of Management in Engineering 17(3): 159-165.

http://dx.doi.org/10.1061/(ASCE)0742-597X(2001)17:3(159)

Kazanjian, R. K.; Drazin, R.; Glynn, M. A. 2000. Creativity and technological learning: the roles of organization architecture and crisis in large-scale, Journal of Engineering and Technology Management 17(3-4): 273-298. http://dx.doi.org/10.1016/S0923-4748(00)00026-6

Keller, R. T. 1986. Predictors of the performance of project groups in R\&D organizations, Academy of Management Journal 29(4): 715-726. http://dx.doi.org/10.2307/255941

Keller, R. T. 1992. Transformational leadership and the performance of research and development project groups, Journal of Management 18(3): 489-501.

http://dx.doi.org/10.1177/014920639201800304

Keller, R. T. 1994. Technology-information processing fit and the performance of R\&D project groups: a test of contingency theory, Academy of Management Journal 37(1): 167-179.

http://dx.doi.org/10.2307/256775

Kloppenborg, T. J.; Opfer, W. A. 2002. The current state of project management research: trends, interpretations, and predictions, Project Management Journal 33(2): 5-18.

Kratzer, J.; Leenders, R. T. A. J.; van Engelen, J. M. L. 2006. Team polarity and creative performance in innovation teams, Creativity and Innovation Management 15(1): 96-104.

http://dx.doi.org/10.1111/j.1467-8691.2006.00372.x

Kwak, Y. H.; Ibbs, C. W. 2002. Project management process maturity (PM) ${ }^{2}$ model, Journal of Management in Engineering 18(3): 150-155.

http://dx.doi.org/10.1061/(ASCE)0742-597X(2002)18:3(150)

Lehmann, V. 2010. Connecting changes to projects using a historical perspective: towards some new canvases for researchers, International Journal of Project Management 28(4): 328-338. http://dx.doi.org/10.1016/j.ijproman.2010.01.011

Leonard-Barton, D. 1995. Wellsprings of knowledge: building and sustaining the sources of innovation. Boston, MA: Harvard Business School Press.

Ling, F. Y. Y.; Low, S. P.; Wang, S. Q.; Lim, H. H. 2009. Key project management practices affecting Singaporean firms' project performance in China, International Journal of Project Management 27(1): 59-71. http://dx.doi.org/10.1016/j.ijproman.2007.10.004

Love, P. E. D.; Holt, G. D.; Shen, L. Y.; Li, H.; Irani, Z. 2002. Using systems dynamics to better understand change and rework in construction project management systems, International Journal of Project Management 20(6): 425-436. http://dx.doi.org/10.1016/S0263-7863(01)00039-4

Luu, V. T.; Kim, S. Y.; Huynh, T. A. 2008. Improving project management performance of large contractors using benchmarking approach, International Journal of Project Management 26(7): 758-769. http://dx.doi.org/10.1016/j.ijproman.2007.10.002 
Mallick, H.; Mahalik, M. K. 2010. Constructing the economy: the role of construction sector in India's growth, Journal of Real Estate Finance and Economics 40(3): 368-384.

http://dx.doi.org/10.1007/s11146-008-9137-z

Miron-Spektor, E.; Erez, M.; Naveh, E. 2007. Balancing innovation attention-to-detail and outcome-orientation to enhance innovative performance, Academy of Management Best Paper Proceedings, August, Philadelphia, USA.

Ochieng, E. G.; Price, A. D. F. 2010. Managing cross-cultural communication in multicultural construction project teams: the case of Kenya and UK, International Journal of Project Management 28(5): 449-460. http://dx.doi.org/10.1016/j.ijproman.2009.08.001

Oke, A.; Idiagbon-Oke, M. 2010. Communication channels, innovation tasks and NPD project outcomes in innovation-driven horizontal networks, Journal of Operations Management 28(5): 442-453. http://dx.doi.org/10.1016/j.jom.2010.01.004

Project Management Institute. 2008. A guide to the project management body of knowledge (PMBOK Guide). 4th ed. Newtown Square, PA: Project Management Institute.

Qureshi, T. M.; Warraich, A. S.; Hijazi, S. T. 2009. Significance of project management performance assessment (PMPA) model, International Journal of Project Management 27(4): 378-388. http://dx.doi.org/10.1016/j.ijproman.2008.05.001

Raiden, A. B. Dainty, A. R. J.; Neale, R. H. 2004. Current barriers and possible solutions to effective project team formation and deployment within a large construction organization, International Journal of Project Management 22(4): 309-316.

http://dx.doi.org/10.1016/j.ijproman.2003.08.002

Raz, T.; Shenhar, A. J.; Dvir, D. 2002. Risk management, project success, and technological uncertainty, $R \& D$ Management 32(2): 101-110. http://dx.doi.org/10.1111/1467-9310.00243

Roman, D. 1964. Project management recognizes R\&D performance, Academy of Management Journal 7(1): 7-20. http://dx.doi.org/10.2307/255229

Schieg, M. 2006. Risk management in construction project management, Journal of Business Economics and Management 7(2): 77-83.

Schieg, M. 2007. Post-mortem analysis on the analysis and evaluation of risks in construction project management, Journal of Business Economics and Management 8(2): 145-153.

Schwab, A.; Anne, S. M. 2008. Learning in hybrid-project systems: the effects of project performance on repeated collaboration, Academy of Management Journal 51(6): 1117-1149.

http://dx.doi.org/10.5465/AMJ.2008.35732606

Scott-Young, C.; Samson, D. 2008. Project success and project team management: evidence from capital projects in the process industries, Journal of Operations Management 26(6): 749-766. http://dx.doi.org/10.1016/j.jom.2007.10.006

Shepherd, D. A.; Patzelt, H.; Wolfe, M. 2011. Moving forward from project failure: negative emotions, affective commitment, and learning from the experience, Academy of Management Journal 54(6): 1229-1259. http://dx.doi.org/10.5465/amj.2010.0102

Song, Y. I.; Lee, D. H.; Lee, Y. G.; Chung, Y. C. 2007. Managing uncertainty and ambiguity in frontier R\&D projects: a Korean case study, Journal of Engineering and Technology Management 24(3): 231-250. http://dx.doi.org/10.1016/j.jengtecman.2007.05.001

Sperpell, A. 1999. Integrating quality systems in construction projects: the Chilean case, International Journal of Project Management 17(5): 317-322.

http://dx.doi.org/10.1016/S0263-7863(98)00048-9

Sun, M.; Meng, X. 2009. Taxonomy for change causes and effects in construction projects, International Journal of Project Management 27(6): 560-572.

http://dx.doi.org/10.1016/j.ijproman.2008.10.005 
Tabassi, A. A.; Bakar, A. H. A. 2009. Training, motivation, and performance: the case of human resource management in construction projects in Mashhad, Iran, International Journal of Project Management 27(5): 471-480. http://dx.doi.org/10.1016/j.ijproman.2008.08.002

Teerajetgul, W.; Chareonngam, C.; Wethyavivorn, P. 2009. Key knowledge factors in Thai construction practice, International Journal of Project Management 27(8): 833-839.

http://dx.doi.org/10.1016/j.ijproman.2009.02.008

Thamhain, H. J. 2009. Leadership lessons from managing technology-intensive teams, Journal of Innovation and Technology Management 6(2): 117-133.

http://dx.doi.org/10.1142/S0219877009001595

Tranfield, D.; Young, M.; Partington, D.; Bessant, J.; Sapsed, J. 2003. Knowledge management routines for innovation projects: developing a hierarchical process model, International Journal of Innovation Management 7(1): 27-49. http://dx.doi.org/10.1142/S1363919603000726

Tukel, O. I.; Rom, W. O. 2001. An empirical investigation of project evaluation criteria, International Journal of Operations and Production Management 21(3): 400-416.

http://dx.doi.org/10.1108/01443570110364704

Wang, E.; Chou, H. W.; Jiang, J. 2005. The impacts of charismatic leadership style on team cohesiveness and overall performance during ERP implementation, International Journal of Project Management 23(3): 173-180. http://dx.doi.org/10.1016/j.ijproman.2004.09.003

Zeng, S. X.; Xie, X. M.; Tam, C. M.; Sun, P. M. 2009. Identifying cultural difference in R\&D project for performance improvement: a field study, Journal of Business Economics and Management 10(1): 61-70. http://dx.doi.org/10.3846/1611-1699.2009.10.61-70

Zou, P. X. W.; Zhang, G.; Wang, J. 2007. Understanding the key risks in construction projects in China, International Journal of Project Management 25(6): 601-614.

http://dx.doi.org/10.1016/j.ijproman.2007.03.001

Hong Long CHEN (Ph.D., University of Florida) is a professor in the department of Business and Management at the National University of Tainan, Taiwan. His research interests are project finance, corporate finance, performance management, and supply chain management. He is a reviewer of several prestigious journals, such as the IEEE Transactions on Engineering Management, International Journal of Project Management, Supply Chain Management: An International Journal, International Journal of Production Economics, Journal of Management in Engineering, Journal of Construction Engineering and Management, and Construction Management and Economics. He is also a member of the editorial board of International Journal of Information Technology Project Management. 